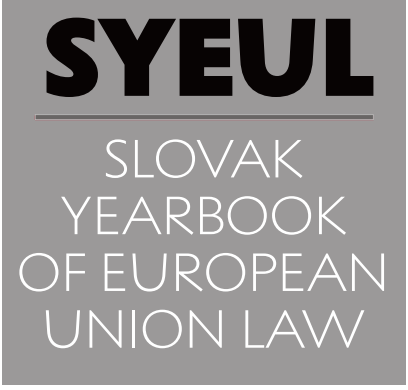

\author{
PUBLISHED BY \\ COMENIUS UNIVERSITY BRATISLAVA \\ FACULTY OF LAW
}

ISSN (print): 2729-8574

ISBN 978-80-7160-585-0

\title{
NEW EU ENLARGEMENT STRATEGY TOWARDS THE WESTERN BALKANS AND ITS IMPACT ON RULE OF
} LAW / Marina Matić Bošković, Jelena Kostić

\author{
Marina Matić Bošković \\ Research Fellow \\ Institute of Criminological and \\ Sociological Research \\ Gračanička 18 \\ Beograd 11000, Serbia \\ m.m.boskovic@roldevelopmentlab. \\ com \\ ORCID: 0000-0003-1359-0276
}

Jelena Kostić

Senior Research Fellow

Institute of Comparative Law

Terazije 41,

11000 Belgrade, Serbia

j.kostic@iup.rs

ORCID: 0000-0001-6032-3045
Submitted: 25 June 2021 Accepted: 30 November 2021 Published: 31 December 2021
Abstract: The rule of law is incorporated in the EU Founding Treaties and case-law of the Court of Justice of the EU and was included as a key requirement already in 1993 Copenhagen accession criteria. The EU enlargement is not only territorial increase, but also transposition of EU acquis to third countries. Since 1993, the monitoring mechanism of the rule of law reform in the $E U$ accession countries was enhanced, including two specific negotiation chapters, Chapter 23 - judiciary and fundamental rights and Chapter 24 - justice, freedom and security. Over the last two decades, the EU was struggling to develop an adequate mechanism in this area, from mechanism for coordination and verification, to action plans for Chapter 23, to more specific tools like perception and experience surveys of the judiciary and functional reviews. Due to the challenges to measure progress and track record in the rule of law, in February 2020 the European Commission presented the new approach to EU Enlargement that aims to push reforms forward. The intention is to make the accession negotiations more credible, predictable and dynamic and criteria for assessing reforms in the accession countries will be based on the clearer criteria and more concise EU requirements. The article examines how EU enlargement policies influenced the rule of law reforms in Western Balkan countries over the years and what could be expected from the new approach. The research hypothesis is based on the correlation between Enlargement strategy towards the Western Balkans and its impact on rule of law in countries of the mentioned region. The methodological approach applied in the assessment is based on analysis of Enlargement strategy and other EU and national documents, as well as results of the work of judicial institutions in order to provide insight into the bottlenecks of the state rule of law in Western Balkan countries and enable identification of recommendations for improvement. The authors concluded that the new methodology would improve the measurability of the achieved results in the rule of law area, however, the approach might slow down the accession process of Serbia and Montenegro as a frontrunners in the process.

Key words: Enlargement policy; rule of law; Western Balkans; reform of judiciary; accession negotiations

\section{Suggested citation:}

Matić Bošković, M., Kostić, J. (2021). New EU Enlargement Strategy Towards the Western Balkans and Its Impact on Rule of Law. Slovak Yearbook of European Union Law, vol. 1, 37-58. https://doi.org/10.54869/syeul.2021.1.248 


\section{INTRODUCTION}

The Treaty Establishing the European Economic Community (Treaty of Rome) from 1957 defined the goals of the European Community through the establishment of a common market, development of uniform economic policies of member states and promotion of balanced development of economic activity, with development of stability, improvement of living standards and connection of member states. ${ }^{1}$ The preamble to the Charter of Fundamental Rights of the European Union speaks of the rule of law, while the existence of the Union is based on the indivisible universal values of human dignity, freedom, equality, solidarity and the principles of democracy and the rule of law. ${ }^{2}$ To enable adequate protection of human rights and social progress, it is necessary to establish and improve the work of institutions important for maintaining and improving the rule of law not only in the member states, but also in the states aspiring to the European Union membership.

The rule of law is of great importance for peace, security, prosperity, social and economic progress. An efficient judiciary is a guarantor of legal certainty, which has a positive effect on business environment, economic development, and above all on encouraging investment (Anderson, Bernstein and Gray, 2005). These values are common to each Member State and to societies ruled by pluralism, non-discrimination, tolerance, justice, solidarity and equality between women and men. ${ }^{3}$ The preamble to the Treaty of Lisbon amending the Treaty on European Union and the Treaty Establishing the European Economic Community from 2007 states that universal values of the inviolable and inalienable human rights, freedom, democracy and the rule of law have developed from the cultural, religious and humanistic heritage of Europe.

To ensure that candidate countries are sharing the same values as the EU member states, the rule of law as an accession requirement was incorporated already in the Copenhagen accession criteria adopted in 1993. Although in the 1990s, during preparation for the biggest EU enlargement that took place in $2004,{ }^{4}$ rule of law was not the primary measure for assessing the progress of the countries in the negotiations, it was one of the key elements. The countries applying for membership were required to meet the criteria for building stable institutions that can guarantee democracy, the rule of law, human rights and respect for and protection of minorities, an efficient market economy, ensuring market competition to strengthen the common market of the European Union, as well as the ability to effectively implement the obligations arising from membership, including obligations arising from the common political, economic and monetary union. During 2006 the rule of law was mentioned as the key element of the EU accession process of Romania and Bulgaria. Based on experience with application of Cooperation and Verification Mechanism with Romania and Bulgaria the European Commission established a new approach to the rule of law during $2012 .^{5}$ The new approach puts rule of law at the heart of the accession process and implies reforms in

\footnotetext{
${ }^{1}$ Article 2 of the Treaty establishing the European Economic Community (EEC). Retrieved from: https://eurlex.europa.eu/legal-content/EN/TXT/HTML/?uri=LEGISSUM:xy0023\&from=EN (date of access: 23.11.2021).

2 The Charter of Fundamental Rights of the European Union, 2007/C 303/01.

${ }^{3}$ Article 1 of the Treaty of Lisbon amending the Treaty on European Union and the Treaty establishing the European Community, 2007/C 306/1.

${ }^{4}$ Eight Central European Countries (two former Soviet republics, four former satellites of the USSR and former Yugoslav republic) and two Mediterranean islands (Malta and Cyprus) joined EU on May 1, 2004, which was the biggest enlargement of the EU (from 15 to 25 member states).

${ }^{5}$ Communication from the Commission to the European Parliament and the Council, Enlargement Strategy and Main Challenges 2012-2013, $\operatorname{COM}(2012) 600$ final. Retrieved from: https://eur-lex.europa.eu/legalcontent/EN/TXT/PDF/?uri=CELEX:52012DC0600\&from=EN (date of access: 23.11.2021).
} 
the accession states with the aim to improve the rule of law and fundamental freedoms. Chapters 23 and 24 are therefore of particular importance to enable monitoring of reforms and compliance with EU standards. The 2015 EU Enlargement Strategy reconfirms that rule of law is the core issue of the EU access process and that countries aspiring to join the Union need to establish and promote from an early stage the proper functioning of the core institutions necessary for securing the rule of law. ${ }^{6}$ In March 2020 the Council of European Union adopted the European Commission proposal for the new enlargement methodology with more focus on fundamental reforms to ensure improvement of the effectiveness of the accession process. ${ }^{7}$

The subject of this paper is an analysis of the influence of EU enlargement policies on the rule of law reforms in the Western Balkan countries over the years and expectations from the new approach. In the first chapter, we start from the assumption that the new approach is justified and that the measures taken so far to monitor the achieved level of rule of law have not given expected results, as well as that it has had a negative impact on citizens' trust in the judiciary. Another assumption is that the implementation of reforms in this area requires political dialogue and a high level of commitment of political leaders. That is why in the first part of the paper we start from the development of the principle of the rule of law as a key element in the process of joining the EU. Having in mind the specificity of the Western Balkans, the paper first looks at the results of the mechanism of cooperation and verification of progress that has been applied in relation to Romania and Bulgaria. Based on the analysis of the European Commission's report on the progress of these countries, we seek to make recommendations for improving the approach to the process of harmonization with EU standards in Serbia and Montenegro. These countries were selected, since they opened negotiation in the rule of law according to one methodology, and recently agreed to apply the new methodology. Therefore, fulfilling the conditions for membership with the application of the new methodology will be a special challenge for them.

Bearing in mind that we also assume that modest progress has been made in the area of judicial reform in Serbia and Montenegro, in the next chapter we analyse the European Commission's progress report, the Venice Commission's Opinion and the reports of various international organizations on progress in this area. Within this part of the paper, we pay special attention to the reports on corruption in the judiciary, as well as the reports on citizens' perceptions of corruption in this area. In this way, we want to point out that the new approach of the European Union is justified and that should contribute to the increased responsibility of countries in terms of meeting the criteria in the rule of law. In this way, we want to point out the justification for the adoption of new tools important for assessing progress in the field of rule of law, which should provide insight into the results achieved in practice.

\footnotetext{
${ }^{6}$ Communication from the Commission to the European Parliament, the Council, the European Economic and Social Committee and the Committee of the Regions, EU Enlargement Strategy, COM (2015) 611 final. Retrieved from:

https://eur-lex.europa.eu/legal-content/HR/TXT/PDF/?uri=CELEX:52015DC0611(01)\&from=EN

(date of access: 23.11.2021).

${ }^{7}$ Communication from the Commission to the European Parliament, the Council, the European Economic and Social Committee and the Committee of the Regions, Enhancing the Accession Process - A Credible EU Perspective for the Western Balkans, COM (2020) 57 final. Retrieved from: https://eur-lex.europa.eu/legalcontent/EN/TXT/PDF/?uri=CELEX:52020DC0057\&from=EN (date of access: 23.11.2021).
} 


\section{THE RULE OF LAW AS A KEY ELEMENT FOR EU ACCESSION}

The rule of law was mentioned as a key condition for EU accession in 2004, when Romania and Bulgaria accession was postponed due to the challenges in the rule of law area, specifically the reform of judiciary and fight against corruption (Pejović, 2016, pp. 14-15). Such an approach was introduced by the Decision of the European Commission on the establishment of a mechanism for cooperation and verification of progress for Romania in order to establish specific criteria in the field of judicial reform and the fight against corruption. ${ }^{8}$

Although Romania was due to become a member of the European Union less than a month after the establishment of above-mentioned decision, the Commission concluded on the basis of its latest report from 2006 on its progress in the Stabilization and Association Process that progress still needed to be taken. At the national level was necessary to strengthen the accountability and efficiency of the judicial system, as well as to improve the capacity of taking adequate measures to protect the internal market, as well as the areas of freedom, security and justice. If Romania would not be able to adequately meet the accession criteria in these areas, the Commission would have been able to apply the measures in accordance with the Accession Treaty. These measures involved non-recognition of Romanian judgments and court decisions such as European arrest warrants in accordance with European Union regulations. ${ }^{9}$

Accordingly, Romania needed to improve the transparency and efficiency of judicial proceedings, and in particular to improve the capacity and accountability of the High Judicial Council. In addition, it was necessary to supervise the application of the Code of Civil Procedure, establish an independent agency for verification of the property origin and potential conflicts of interest, and for professional and independent investigations of high-level corruption. In addition, it was necessary to take measures in the field of prevention and fight against corruption, and subsequently at the level of local self-government units. The above-mentioned represents the criteria on the basis of which Romania's progress in assessing the responsibility and efficiency of the judicial system, and the area of freedom, security and justice was assessed.

In line with the Decision, Romania was obliged to report to the Commission by 31 March each year on progress in areas where it needed to make additional efforts to meet the membership criteria. In this regard, the Commission undertook to provide technical assistance through various activities, including the exchange of information regarding the achievement of benchmarks in the disputed areas. In addition, the Commission had the right to organize an expert mission in Romania at any time to verify the fulfilment of the disputed membership criteria, while the obligation of the Romanian authorities and competent authorities was to support the European Commission in verifying the fulfilment of criteria in the disputed areas. ${ }^{10}$ In order to keep the European Parliament informed of Romania's progress, the Commission was obliged to report to it

\footnotetext{
${ }^{8}$ Commission Decision 2006/928/EC of 13 December 2006 establishing a mechanism for cooperation and verification of progress in Romania to address specific benchmarks in the areas of judicial reform and the fight against corruption, Official Journal of the European Union, L 354/56. Retrieved from: https://eurlex.europa.eu/legal-content/EN/TXT/PDF/?uri=CELEX:32006D0928\&from=EN (date of access: 23.11.2021).

${ }^{9}$ Ibid., Paragraph (7).

10 lbid., Article 1.
} 
regularly every six months on the progress in the disputed areas as long as there was a need to undertake such activity. ${ }^{11}$

The similar Decision was adopted during the 2006 for Bulgaria. ${ }^{12}$ The criteria that Bulgaria was supposed to meet were the adoption of constitutional amendments that would remove any impact on the independence of the judicial system, and which should also improve accountability in this area. Bulgaria had an obligation to ensure greater transparency and efficiency of the judicial system by adopting and implementing a new law governing the judicial system, as well as a new Criminal Procedure Code, regularly reporting on the implementation of the new Criminal and Administrative Procedure Code, and in particular the implementation of the new Criminal Procedure Code during the pretrial proceedings.

In addition, the criteria are defined as continuous reform of the judicial system in order to improve professionalism, accountability and efficiency, measuring the impact of these reforms and annual publication of results, conducting and reporting on professional and independent investigations into high-level corruption, taking further measures in the field of prevention and the fight against corruption, especially at the level of local self-government units, implementing the anti-corruption strategy, with a special focus on serious crimes, money laundering, as well as the confiscation of criminal assets and reporting on new and ongoing investigations, charges and judgments in that area. ${ }^{13}$ Reports on Cooperation and Verification Mechanism proved that it is not enough just to monitor progress in relation to the existence of legal acts and strategic documents, but that it is necessary to analyse the results achieved in practice. In addition, the above examples show that in order to improve the principles of the rule of law at the national level, it is necessary to have political will and inter-institutional cooperation. ${ }^{14}$

Accession negotiations with Bulgaria and Romania revealed that shortcomings in key areas such as reform of the judiciary and the fight against organised crime and corruption had not been fully overcome. To remedy the identified shortcomings in the enlargement process, the 2005 negotiating frameworks for Croatia and Turkey introduced a specific chapter 23 - "judiciary and fundamental rights" - in addition to the previously existing and then renumbered chapter 24 - "justice, freedom and security" (Butković and Samardžija, 2014, pp. 91-108). Both chapters cover key rule of law issues, in particular reform of the judiciary and the fight against organised crime and corruption.

\footnotetext{
11 Ibid., Article 2.

${ }^{12}$ Commission Decision 2006/929/EC of 13 December 2006 establishing a mechanism for cooperation and verification of progress in Bulgaria to address specific benchmarks in the areas of judicial reform and the fight against corruption and organised crime, Official Journal of the European Union, L 354/58. Retrieved from: https://eur-lex.europa.eu/LexUriServ/LexUriServ.do?uri=OJ:L:2006:354:0058:0060:EN:PDF (date of access: 23.11.2021).

13 Ibid.

${ }^{14}$ Report from the Commission to the European Parliament and the Council on Progress and Verification Mechanism, COM(2018) 851 final and Report from the Commission to the European Parliament and the Council on Progress in Romania under the Cooperation and Verification Mechanism, COM(2019) 499 final; Report from the Commission to the European Parliament and the Council on progress in Bulgaria under the Cooperation and Verification Mechanism, $\operatorname{COM}(2019) 498$ final. Retrieved from: https://ec.europa.eu/info/policies/justice-and-fundamental-rights/upholding-rule-law/rule-law/assistancebulgaria-and-romania-under-cvm/reports-progress-bulgaria-and-romania_en (date of access: 23.11.2021).
} 
Despite certain drawbacks, the introduction of opening and closing benchmarks as a novelty in the accession negotiations has proved an effective tool.

Lessons learned from previous enlargements influenced on introduction of the rule of law as a key element for the EU enlargement. ${ }^{15}$ The new approach to negotiations in the areas of justice, fundamental rights, freedom and security has already had an impact on the negotiating framework adopted in 2012 for Montenegro and later applied also to Serbia. Based on the experience with Croatia, the EU developed the "new approach", which included placing priority on the fundamental areas (the rule of law and fundamental rights, justice, freedom and security), demanding track record, introducing interim benchmarks during the negotiations to tackle the emerging issues, and a suspension clause in case of the serious breach of countries' commitments (Maric and Bajić, 2018). With regard to the judicial system, countries aspiring to membership had to ensure the independence of the judiciary, objectivity, accountability, as well as respect for the principles of fairness. One of the requirements they had to meet was to improve the efficiency of the judicial system, with special reference to a trial within a reasonable time. $^{16}$

However, during 2020, a new methodology was adopted for Northern Macedonia and Albania. ${ }^{17}$ Bearing in mind that Serbia and Montenegro were already in the process of accession negotiations, they had the opportunity to determine whether further negotiations would be continued according to the existing or new methodology. Both countries voted for the second option. According to the new methodology, the new chapters will not be able to be closed before the transitional criteria concerning the rule of law are met, and with the possibility of applying corrective measures if problems arise during the negotiations. The new methodology envisages that Chapters 23 and 24 will close the last, and open between the first to provide enough time for the necessary negotiations. Within the new methodology, a special novelty in the negotiation is clustering chapters (six clusters in total), which in relation to Serbia implies the grouping of already existing negotiating areas. The cluster on fundamentals (rule of law, economic criteria and public administration reform) will take a central role and sufficient progress will need to be achieved before other clusters can be open.

\section{IMPACT OF THE ACCESSION PROCESS ON THE JUSTICE REFORM}

Consequently, countries aspiring to the EU membership were obliged to implement judicial reforms to align judicial legislation and practice with the EU standards on independent, accessible and efficient judiciary. However, after almost two decades of the judicial reform in the Western Balkans countries, the EU is still reporting that these countries remain moderately prepared to apply the EU acquis and the European standards in the Chapter 23 area and that have made limited progress overall. ${ }^{18}$ This is

\footnotetext{
${ }^{15}$ Communication from the Commission to the European Parliament and the Council, "Enlargement Strategy and Main Challenges 2012-2013, $\operatorname{COM(2012)~} 600$ final. Retrieved from: https://eur-lex.europa.eu/legalcontent/EN/TXT/PDF/?uri=CELEX:52012DC0600\&from=EN (date of access: 23.11.2021).

${ }^{16} \mathrm{Ibid}$.

${ }^{17}$ Communication from the Commission to the European Parliament the Council, the European Economic and Social Committee and the Committee of the regions, 2020 Communication on EU enlargement policy. Retrieved from: https://eur-lex.europa.eu/legal-content/GA/TXT/?uri=CELEX:52020DC0660 (date of access: 23.11.2021).

18 Montenegro 2020 Report Accompanying the Communication from the Commission to the European Parliament, the Council, the European Economic and Social Committee and the Committee of the Regions
} 
specifically worrying for Montenegro and Serbia, since these two countries were seen as frontrunners in the EU accession process. ${ }^{19}$ Both, Serbia and Montenegro adopted three judicial reform strategies as a key policy documents that are defining framework and direction of reforms.

The assessment of the accession process impact on justice sector is focused on two Western Balkans countries that were recognized as frontrunners. Also, negotiation process on Chapter 23 has been opened in Montenegro since December 2013 and in Serbia since July 2016, which enable stronger influence on the reforms through Screening report, approval of Action plan for Chapter 23 and monitoring of its implementation.

\subsection{Impact on the Judiciary}

Key reforms included changes of the legislative framework and the introduction of new institutions and new judicial professions. Adoption of new Constitution or amendments to the Constitution were needed in all Western Balkan countries to guarantee independence of judiciary and removal of political influence over the process of appointment of judges and prosecutors. The Venice Commission is the main EU partner and the EU relies on their opinions in relation to independence of judiciary and legislative reforms. When it comes to the efficiency of the justice system, the EU is partnering with the Council of Europe Commission for the Efficiency of Justice (CEPEJ) that is active in setting indicators and standards for judicial efficiency and quality (Albers, 2008, pp. 9-25). However, all these efforts and reforms in candidate countries had limited and mixed results.

Although Serbia adopted a new Constitution in 2006, ${ }^{20}$ which in many aspects meet European standards, further adjustments are required to align with the European standards. Many recommendations stipulated in the 2005 Venice Commission Opinion were adopted and implemented into the 2006 text. ${ }^{21}$ However, the Venice Commission in its Opinion from 2007 underlined that there is still an overall impression of an excessive

2020 Communication on EU Enlargement Policy, Brussels, 2020; Serbia 2020 Report Accompanying the Communication from the Commission to the European Parliament, the Council, the European Economic and Social Committee and the Committee of the Regions 2020 Communication on EU Enlargement Policy, Brussels, 2020; Bosnia and Herzegovina 2020 Report Accompanying the Communication from the Commission to the European Parliament, the Council, the European Economic and Social Committee and the Committee of the Regions 2020 Communication on EU Enlargement Policy, Brussels, 2020; North Macedonia 2020 Report Accompanying the Communication from the Commission to the European Parliament, the Council, the European Economic and Social Committee and the Committee of the Regions 2020 Communication on EU Enlargement Policy, Brussels, 2020; Albania 2020 Report Accompanying the Communication from the Commission to the European Parliament, the Council, the European Economic and Social Committee and the Committee of the Regions 2020 Communication on EU Enlargement Policy, Brussels, 2020; Kosovo 2020 Report Accompanying the Communication from the Commission to the European Parliament, the Council, the European Economic and Social Committee and the Committee of the Regions 2020 Communication on EU Enlargement Policy, Brussels, 2020.

${ }^{19}$ Communication from the Commission to the European Parliament, the Council, the European Economic and Social Committee and the Committee of the Regions, A Credible Enlargement Perspective for Enhanced EU Engagement with the Western Balkans, COM (2018) 65 final, p. 7. Retrieved from: https://ec.europa.eu/info/sites/default/files/communication-credible-enlargement-perspective-westernbalkans_en.pdf (date of access: 23.11.2021).

20 The Official Gazette of the Republic of Serbia, no. 98/2006.

21 Venice Commission, Comments on the Provisions on the Judiciary in the Draft Constitution of the Republic of Serbia, CDL (2005) 072, Opinion No. 349/2005, 4 October 2005. Retrieved from: https://www.venice.coe.int/webforms/documents/?pdf=CDL(2005)072-e (date of access: 23.11.2021). 
influence of parliament on the judiciary. ${ }^{22}$ To ensure direction and systemic approach to the reforms, several policy documents on judiciary were adopted and implemented with the mixed results. The first National Judicial Reform Strategy covered the period 2006 2011. Under this policy document, a legal and institutional framework for the judiciary was established, as well as the process of significant reorganization of court network and re-appointment of judges and public prosecutors in 2009 (Rakić Vodinelić, Knežević Bojović and Reljanović, 2012) which was carried out in an unconstitutional manner (International Commission of Jurists, 2016, p. 5). The High Judicial Council and State Prosecutorial Councils were established in 2009 with the aim to guarantee independence and autonomy of judiciary. However, some key issues had not been resolved. The full transfer of competencies to the Councils had never happened and as a result governance over the judicial system is split between the Ministry of Justice and the Councils, ${ }^{23}$ which in some segments have impact on independence of judiciary (i.e. financial independence, management of human resources). In addition, the capacities of the Administrative offices of the Councils are lacking analytic staff that could support policy development and implementation of reform activities.

The second wave of reforms in Serbia are framed by the National Judicial Reform Strategy for period 2013-2018. The aim of the reform was to increase the quality of justice, efficiency, effectivity and independence. The new court network was established in January $2014^{24}$ to enable a reduction of the case backlog, and to provide more equitable case distribution. During the implementation of the 2013 Strategy, a new judicial professions were introduced (notaries and bailiffs) and transfer of some of the court's competencies to the new professions; transparency of the judicial system increased, through the publishing of the HJC and the SPC decisions, and development courts and public prosecutor offices (PPOs) websites. In addition, numerous services for citizens were established to improve access to justice, including the e-Justice portal and free legal aid system. ${ }^{25}$ In the area of independence of judiciary, the Councils had challenges in establishing mechanisms for the protection of judges and prosecutors against undue influences. Only in 2017, the State Prosecutorial Council introduced Commissioner for autonomy which was recognized by the European Commission as an elaborated mechanism to react in cases of undue influence on the work of public prosecutors and deputy public prosecutors (European Commission, 2020, p. 21). However, after expiration of mandate of the first Commissioner, the new was not appointed, which raise consideration for sustainability of the mechanism. The HJC was also oriented towards the establishment of the ethical boards as permanent bodies that should protect independence of judges, however, the Ethical board reaction in cases of undue influences was limited (European Commission, 2018b, p. 14).

\footnotetext{
22 Venice Commission, Opinion No. 405/2006, Opinion on the Constitution of Serbia, 19 March 2007, para. 60. Retrieved from: https://www.venice.coe.int/webforms/documents/default.aspx?pdffile=CDL-AD(2007)004-e (date of access: 23.11.2021).

23 Serbian Judicial Functional Review 2014. Washington: World Bank. Retrieved from: https://www.mdtfjss.org.rs/archive//file/Serbia\%20Judicial\%20Functional\%20Review-Full\%20Report.pdf (date of access: 23.11.2021); and Functional Review of the Prosecution System in Serbia (2019). Washington: World Bank. Retrieved from:

https://www.mdtfjss.org.rs/archive/file/SRB\%20Prosecution\%20FR\%20December\%202018.pdf (date of access: 23.11.2021).

24 The Official Gazette of the Republic of Serbia, no. 101/2013.

25 USAID (2018). Rule of Law Project. Assessment of the Implementation of the National Judicial Reform Strategy 2013-2018, 1 November 2018 pp. 5-6. Retrieved from: https://en.rolps.org/public/documents/upload/Assessment\%20of\%20the\%20NJRS\%20Implementation, $\% 20$ short\%20version,\%20ENG,\%20final,\%2001112018.pdf (date of access: 23.11.2021).
} 
A range of legal safeguards were introduced during previous years to protect the independence of the judiciary, but reforms to remove vestiges of dependence have been delayed, since the Constitutional reform has been put on hold due to the lack of social consensus. Among other changes, draft Constitutional amendments which have been proposed would remove the Assembly's approval of judicial appointments. ${ }^{26}$ Challenges in practice, like exercise of undue influence and public comments by government officials on investigations and ongoing court proceedings impacted Serbia ranking on world indices (European Commission, 2018b, p. 14). The 2019 World Economic Forum's Global Competitiveness Report ${ }^{27}$ ranked Serbia's judiciary $101^{\text {st }}$ out of 141 countries for judicial independence. Serbia fell behind all EU countries except Croatia and Poland. The results are similar in the 2019 Bertelsmann Transformation Rule of Law Index, ${ }^{28}$ in which Serbia ranked below all the countries of the EU11: its score for Serbia's judicial independence was 6.0 out of 10 in 2014 and remained unchanged from 2009. ${ }^{29}$

A similar impact of the reforms and EU accession process as a key driver could be noticed in Montenegro. Reforms started with the amendments to the Constitution in 2013. After XVI constitutional amendments, most of them related to the judiciary, a rationalization of parts of the judicial network was conducted from 2013 to 2015, alongside the introduction of the Prosecutorial Council in 2013. Montenegro's Parliament adopted its second Strategy for the Reform of the Judiciary in April 2014, ${ }^{30}$ and the same year private bailiffs were introduced as a new judicial profession that should contribute to the improvement of efficiency of the judiciary. In 2015 the Center for Training in Judiciary and State Prosecution was established as an autonomous body, while the new system for a judicial appointment was introduced in October 2016. Despite numerous legislative changes, the application of the law in practice remains a concern. The decision of Judicial Council to re-appoint the President of the Supreme Court for the third mandate and six presidents of the basic court for another term, despite article 124 of the Constitution that stipulates that "the same person may be elected the president of the Supreme Court no more than two times" was a major judicial issue in 2020. However, it presents only the culmination of the malpractice and lack of integrity demonstrated by the Judicial Council and other judicial stakeholders thought the last decade. The Council of Europe Group of States against Corruption (GRECO) has already recommended abolishing the ex-officio participation of the Minister of Justice in the Council, by providing for no less than half of the Council's membership to be composed of judges who are elected by their peers and by ensuring that the presiding function is given to one of those

\footnotetext{
${ }^{26}$ Venice Commission, Opinion No. 921/2018, Opinion on the draft amendments to the constitutional provisions on the judiciary, 25 June 2018.

Retrieved from: https://www.venice.coe.int/webforms/documents/default.aspx?pdffile=CDL-AD(2018)011-e (date of access: 23.11.2021.).

${ }^{27}$ The Global Competitiveness Report 2019 assesses the competitiveness landscape of 148 economies via over 15,000 Executive Opinion surveys with 15,000. Its definition of independence includes influences on judicial decision-making from members of government and firms. Retrieved from: https://reports.weforum.org/global-competitiveness-report-2018/ (date of access: 23.11.2021).

28 The Bertelsmann Stiftung's Transformation Index (BTI) analyses and evaluates the quality of democracy, a market economy and political management in 137 developing and transition countries. It measures successes and setbacks on the path toward a democracy based on the rule of law and a socially responsible market economy. For more details see BTI: Transformation Index. Methodology. Available at: https://www.btiproject.org/en/methodology.html\#country-selection (date of access: 23.11.2021).

29 The lowest score in the EU11 is Hungary's, which scored 7.0. Estonia and Lithuania received top marks of 10

${ }^{30}$ First Judicial Reform Strategy was adopted for period 2007-2012.
} 
judicial members. ${ }^{31}$ Despite GRECO recommendations, the independence of the Judicial Council remains questionable since the composition of the Council is still not in line with EU criteria for ensuring independence. The fact that the Minister of Justice and the President of the Supreme Court are still ex officio members, is the primary concern that makes Judicial Council prone to political influence. In addition to that, another jeopardy presents the fact that four of the eight were judges elected by their peers, while the remaining four were elected from among distinguished lawyers by a qualified majority of the Parliament.

Many recommendations of Consultative Council of European Judges (CCJE), and GRECO are still not implemented and since Judicial Council remains the main internal stakeholder, there is no doubt that it is the most accountable and that affairs surrounding it alongside reluctance to engage in more profound judicial reforms had a great impact on the perception primarily by citizens. The case-law of the European Court of Human rights acknowledges that a judicial council may have a mixed composition of judges and non-judges, but only if most of its members are judges elected by their peers, which was not the case in Montenegro. The CCJE and GRECO also recommend that the chair of the Judicial Council be a judge, but in Montenegro, the chair had to be one of its non-judge members. Moreover, the fact that the Minister of Justice is one of the Council's ex officio members could lead to the placement of undue political pressure on the other Council members. Contrary to CCJE and GRECO's recommendations that the chair of the Judicial Council should be a judge, Montenegro's current constitutional arrangements stipulate that the chair of the Judicial Council will be elected from among its non-judge members, which also posed a risk for the politicization of this important judicial governance body.

However, a number of challenges remained at the time, specifically in the area of judicial independence and efficiency of the judiciary. In particular, challenges related to balancing the process of electing judges and public prosecutors in order to strike an adequate balance between independence and accountability, including specific challenges such as the immunity of judicial officials and the reduction of large backlogs. In addition, enforcement of court decisions is still a challenge in both Serbia and Montenegro.

Although authorities in Western Balkan countries were putting efforts to strengthen rules on the appointment of judges and court' presidents, effective implementation is lacking. In Montenegro on January $1^{\text {st }}, 2016$, provisions of the Law on Judicial Council and judges regulating the appointment procedure came into force. It provided regulation regarding terms and procedure for the election of judges and presidents of courts, Plan of vacant positions, promotion and appraisal. The Judicial Council implemented for the first time the procedure concerning the appointment of judges and presidents of courts through the adoption of the plan of vacant positions for judges and by establishing a committee that participates in the election process, and by having internal and public announcements of vacancies. In the first elections of judges according to the unique list of candidates in October 2016, in the election of 3 candidates

\footnotetext{
${ }^{31}$ In addition to this recommendation, GRECO report also mentioned: establishing objective and measurable selection criteria for non-judicial members which would endorse their professional qualities and impartiality; and setting in place operational arrangements to avoid an over-concentration of powers in the same hands concerning the different functions to be performed by members of the Judicial Council, see GRECO (2019).
} 
Judicial Council, without any explanation, did not apply Plan of vacant positions adopted in 2015. ${ }^{32}$

In Serbia to improve the efficiency of the judiciary, a number of procedural laws were amended, such as Criminal Procedure Code, Civil Procedure Law, Bankruptcy Law, Law on General Administrative Procedure, Law on Non-Contentious Proceedings. Amendments to the law on enforcement and security of July $2019,{ }^{33}$ which entered into force in January 2020, transferred additional types of enforcement cases from courts to public enforcement agents. However, a new appeal system to better protect individual debtors and strengthen court control over public enforcement agents was introduced but was not followed by additional human resources in courts. Although this reform led to a reduction of old cases (in 2018 in total 311,018 old cases were resolved out of which 140,452 were enforcement cases, and in 2019 in total 214,234 cases were resolved, out of which 112,473 were enforcement cases), there are still some 252,210 cases in basic courts and 1,184 in second instance courts older than 10 years, mostly dealing with civil matters (European Commission, 2020, p. 23). Timeliness of case processing, measured via the CEPEJ disposition time indicator, significantly improved nationally although individual court types reported mixed results. The total disposition time of all Serbian courts astoundingly decreased from 580 days in 2014 to 267 days in 2019. In 2016, it reduced temporarily even more, to 253 days, due to the reductions in enforcement backlogs triggered by the transfer of large number of the cases from the courts to private enforcement bailiffs. Although timeliness increased overall, the highest disposition time per court type in Serbia in 2019 was 20 times greater than the lowest. ${ }^{34}$ The total congestion ratio of courts in Serbia improved considerably and dropped to 0.73 in 2019, but the court system was not handling its pending stock as efficiently as it could have. As a consequence of mixed reform results the European Commission 2020 Report on Serbia recognized there had been advances in efficiency and backlog reduction but warned of the high number of pending backlog cases and significant differences in workloads across the country (European Commission, 2020).

Montenegro judiciary put a lot of effort into the period between 2013 and 2018 to address the issue of the backlog and judicial efficiency. There was given the legal possibility of the temporary transfer of judges to another court was used as well as the delegation of cases and overtime, ${ }^{35}$ including the adoption of Law on Courts. ${ }^{36}$ However, the Law on the Protection of the Right to Trial within a Reasonable Time that was adopted to improve efficiency demonstrated a number of deficiencies. ${ }^{37}$ Compared to the Council of Europe average duration of cases, the Montenegro judiciary stands well. In CEPEJ report 2020 (2018 data), disposition time in civil and commercial litigious cases at first

\footnotetext{
32 Human Rights Action and Monitoring and Research Center (2017). Report on implementation of Judicial Reform Strategy 2014-2016, Podgorica: HRA Montenegro, CEMI. Retrieved from: https://cemi.org.me/wpcontent/uploads/2017/04/IZVJE\%C5\%A0TAJ-O-REALIZACIJI-STRATEGIJE-REFORME-PRAVOSU\%C4\%90A2014-2016.pdf (date of access: 23.11.2021)

33 The Official Gazette of the Republic of Serbia, no. 54/2019.

${ }^{34}$ Supreme Court of Cassation, Annual report: the highest disposition time in 2019 per court type was reported by the Administrative Court with 665 days (an improvement from 2018 but still roughly 100 to 200 days higher than from 2014 to 2017); the lowest was reported by the Appellate Misdemeanour Court at 34 days.

35 Strategy for the Reform of the Judiciary 2019-2022, Montenegro Ministry of Justice, Podgorica. Retrieved from: https://www.gov.me/dokumenta/deb3e3ae-7b6a-4963-9b3e-b5892118c8c8 (date of access: 23.11.2021.).

${ }^{36}$ Law on Courts, Official Gazette, no. 11/2015, 76/2020

37 Vebsajt RTCG (2019). ZAKON O ZAŠTITI PRAVA NA SUĐENjE U RAZUMNOM ROKU: Neophodno unapređenje Zakona jer ne daje potrebne rezultate. In: Paragraf Lex MNE. Retrieved from: https://www.paragraf.me/dnevne-vijesti/20112019/20112019-vijest2.html (date of access: 23.11.2021).
} 
instance in Montenegro was 229 days, with the European average being 233. Furthermore, the disposition time of first instance criminal cases in Montenegro was 199, while the European average was 199 (European Commission for the Efficiency of Justice, 2020). While the average duration of the case is not long, the amplitudes in durations are substantial, which is confirmed in the ECtHR decisions. Montenegrin judicial system struggles to comply fully with ECHR requirements of the right to a fair trial within a reasonable time and in 2020 only, 8 out of 10 judgments of ECtHR determined the violation of the right to a fair trial within a reasonable time. On top of that, out of 120 complaints Judicial Council received during 2020, a significant part of the referred to the long duration of the procedure..$^{38}$

\subsection{Impact on Anti-corruption}

Despite numerous anti-corruption initiatives and some improvements in the normative and institutional frameworks, prevention of judicial corruption and impunity remained an issue of concern in Serbia. There still was no effective coordination mechanism in place for the prevention of and reduction or elimination of corruption. In October 2020 the GRECO found that since 2015, Serbia had satisfactorily implemented only two of GRECO'S 13 recommendations regarding "Corruption prevention in respect of members of parliament, judges and prosecutors," ${ }^{39}$ which led to the evaluation of the situation as 'globally unsatisfactory'." 40

Although the fight against corruption was among the Government priorities over the last decade, the corruption remains the area of concern according to Serbia ranking in international indices and European Commission Reports on Serbia (European Commission, 2020, p. 6). Serbia ranked 94 out of 180 countries in the 2020 corruption perception index, while it was 91 in 2019 and 87 in 2018. ${ }^{41}$ Also, according to the 2020 USAID Citizens' Perceptions of Anti-corruption Efforts in Serbia, $54 \%$ of the respondents believe that corruption is greatly and extremely widespread in Serbia, ${ }^{42}$ while $44 \%$ have a perception that corruption exists in judiciary. ${ }^{43}$ While $57 \%$ of the respondents from Belgrade believe that corruption is present in judiciary to a large extent, $35 \%$ of the respondents from Central Serbia share the same view. ${ }^{44}$ Also, $72 \%$ believe that the Public Prosecutors' Office is not at all committed to fighting corruption, and that corruption is present in this institution to a large extent. ${ }^{45}$ In addition, roughly 10 percent of citizens reported they gave a gift, paid a bribe or did a favour for personnel in courts and

\footnotetext{
38 The Supreme Court took some steps in order to assess reasons for the extensive duration of judicial proceedings in civil law matter. Two Analyses of court cases have been conducted in Pilot courts in Kotor and Podgorica. The focus was on the cases older than five years; however, the results of this analysis are not available, which presents the issue for a potential wider debate on this matter.

${ }^{39}$ Group of States against corruption (2020). GRECO's Fourth Evaluation Round, "Corruption prevention in respect of members of parliament, judges and prosecutors" Second Compliance Report, Strasbourg: Group of States against corruption and Council of Europe, para 80 and 86. Retrieved from: https://rm.coe.int/fourthevaluation-round-corruption-prevention-in-respect-of-members-of/1680a07e4d

(date of access: 23.11.2021.).

$40 \mathrm{lbid}$.

${ }^{41}$ Serbia shares this position with Brazil, Ethiopia, Kazakhstan, Peru, Sri Lanka, Suriname and Tanzania. For more details see Transparency International (2020).

42 USAID (2020). Opinion Poll Report: Citizen's Perceptions of Anti-Corruption Efforts in Serbia 2020 (III Cycle), November 2020, p. 12. Retrieved from: https://www.odgovornavlast.rs/wp-content/uploads/2020/12/USAIDGAI-Citizens'-Perceptions-of-Anticorruption-Efforts-in-Serbia-2020-1.pdf (date of access: 23.11.2021).

43 Ibid., p. 29.

44 Ibid., p. 28.

45 Ibid., p. 29
} 
prosecution offices. ${ }^{46}$ Among those, the majority said they offered a bribe to obtain faster service, while others wanted a service they were not entitled to, or sought to avoid responsibility for their actions.

In Montenegro lack of integrity, alongside lack of effective monitoring and accountability of the work of judicial professionals, are preventing Montenegro from improving rankings within the relevant international lists and indexes. At the Transparency international index list 2020, Montenegro is ranked $45^{\text {th }}$ out of 180 countries for the fourth consecutive year. A significant drop in the WGI Index for the areas of Voice and Accountability and Control of Corruption was recorded from 2018 to 2019. This fall is rather insightful since the accountability of the members of the judiciary, primarily judges and prosecutors in conjunction with corruption presents substantial problems that Montenegro is struggling with for a long time.

The perception of corruption in the judicial system of Montenegro polarizes providers and users (World Bank Report, 2018, p. 95). On the one side, according to citizens, corruptive practices are present to a large extent while according to judges and prosecutors it seems it is a very rare phenomenon. It is striking that almost all providers of court services state that there is no corruption in the judiciary, while more than $60 \%$ of users and $29 \%$ of lawyers believe that corruption is present.

Several affairs regarding corruption and judiciary occurred during 2019 and 2020, especially the "envelope" affair and the affair of the free apartments given to some public officials. These and other similar high-profile cases should be taken with great caution since they influence heavily the citizens' perception. Conducting an appropriate investigation and, if necessary, trial, or failing to do so are indicated in the perception of the state of the judiciary and the fight against corruption in the country. For example, while the judicial outcome of the "envelope" affair occurred in 2021, the entire process demonstrated the essence of the mistrust in judicial independence in Montenegro (Tomović, 2021).

In relation to the accountability, the disciplinary systems for judges and prosecutors in Montenegro are complex and were not invoked often. Despite some improvement in the number of cases, track records on the enforcement of the codes of ethics and disciplinary accountability for judges and prosecutors remain poor. ${ }^{47}$

\section{MEASURING PROGRESS IN THE RULE OF LAW AREA}

One of the key preconditions for successful reforms in the justice sector and management of judiciary is existence of the robust evidence and analysis underpinning the design of reforms. Stakeholders are now interested if policies, programmes and projects led to desired outcomes and results (Kusek and Rist, 2004). It is widely accepted by all relevant stakeholders that for building results-based monitoring and evaluation systems and making necessary decisions in the process of justice reforming there should be necessary statistical data which would be strong ground for doing reforms in the right directions (Matić Bošković, 2017, pp. 77-92). Statistical data should be valid, verifiable, transparent and widely available to the government and interested stakeholders.

The European Commission in assessing progress in the judicial reforms relies on national judicial statistics on the countries aspiring to the EU membership. In addition, the EU develop its own tools to oversight progress and also used external sources such

\footnotetext{
46 Ibid.

${ }^{47}$ Annual report of the Judicial Council on overall situation in judiciary for 2020, Montenegro Judicial Council, 2021.
} 
as opinions of the Venice Commissions on the Constitutions and relevant judicial laws, GRECO evaluation reports on anti-corruption efforts and judiciary (IV evaluation round), ranking in the international indices, such as rule of law index.

In the case of Bulgaria and Romania EU accession, the European Commission used the Cooperation and Verification mechanism, as ex post control after accession to the EU (Gateva, 2016, p. 83). Use of this mechanism represents the exception and requires extensive engagement of the European Commission. The Cooperation and Verification Mechanism progress reports on Romania took into consideration four main criteria: judicial independence and reform, integrity, high-level corruption and corruption at all levels. Each of these areas are finely and profoundly analysed and the reports present both positive and negative aspects. Recommendations are the most important elements of these CVM reports because they reflect the European Union conception on the rule of law. In the progress reports the European Commission was assessing practice and implementation of laws, including process of appointment of judges, successful prosecution and conviction for high level corruption cases. However, the experience with Romania showed that internal democratic backsliding cannot be counteracted by the Cooperation and Verification Mechanism (European Commission, 2018a, p. 1).

Experience with Bulgaria and Rumania in which significant shortcomings remain after accession to the EU, influence on the amendments of the Commission approach and introduction of approach that opening benchmark for Chapters 23 is adopted an Action plan that should provide the answer on recommendations from the Screening report and should lead to achievement of the interim benchmarks. This approach was applied in the accession process of Montenegro and Serbia.

The method of assessing progress is linked to the implementation of the Action plan for Chapter 23. ${ }^{48}$ The Action plan for Chapter 23 for Serbia listed activities that are relevant for reform of judiciary in Serbia: amendments of Constitution to improve independence and accountability of judiciary, including selection, promotion and dismissal of judges and public prosecutors, appointment of court presidents and introduction of mechanism for prevention of political influences; role of National assembly in the appointment of members of the High Judicial Council and State Prosecutorial Council could be only declaratory and composition of the Councils should be pluralistic. Both, Montenegro and Serbia, established structures for implementation of the Action plan, but also for reporting on implementation. The Ministries of Justice in both countries were leading the process, while European Commission prepares biannual reports: Annual progress reports on progress (each April) and Non-papers on Chapters 23 and 24 (each November). However, the reports on implementation of the Action plan for Chapter 23 were activity based and the Commission got into the situation that Serbian reports on implementation showed that more than 70 percent of the activities related to the judiciary were implemented and additional 10 percent are partially implemented, ${ }^{49}$ while the European Commission annual reports on Serbia are recognizing only moderate or no progress.

These tools used in Serbia and Montenegro showed weaknesses in measuring impact, especially in relation to achievements of interim benchmarks. To overcome these challenges and to enable measuring of reforms impact the European Commission developed additional tools such as Regional Justice Survey and Justice Dashboard

\footnotetext{
${ }^{48}$ Action plan for Chapter 23. Retrieved from: https://www.mpravde.gov.rs/tekst/9849/finalna-verzija-akcionog-plana-za-pregovaranje-poglavlja-23-koja-jeusaglasena-sa-poslednjim-preporukama-i-potvrdjena-od-strane-evropske-komisije-u-briselu-php (date of access: 23.11.2021).

49 Statistical report on implementation of the Action plan for Chapter 23, July 2018. Retrieved from: https://www.mpravde.gov.rs/files/Statistical\%20report\%20on\%20implem\%20entation\%20of\%20AP\%20for\% 20CH\%2023.pdf (date of access: 23.11.2021).
} 
(Council of the EU, 2021). The Regional Justice Survey is implemented for the first time in Western Balkans countries in 2020 with the aim to set-up a baseline against which the progress will be measured regularly. The Regional Justice Survey is based on an analysis of the perceptions and experiences of citizens, businesses and lawyers and service providers (judges, prosecutors and court staff). The comprehensive survey methodology will enable measuring of impact of the judicial reforms in the area of efficiency, quality, independence and integrity. Justice Dashboard will complement the surveys by providing reliable statistics and analysis of justice data.

\section{THE NEW ENLARGEMENT STRATEGY AND THE RULE OF LAW}

Given the challenges facing countries aspiring to EU membership, as well as the long-term nature of reforms, the chapter on justice, fundamental rights, the rule of law, freedom and security, this should be addressed at an early stage of the negotiations to enable that countries have sufficient time to establish adequate legislation, institutions and prove compliance with the criteria before closing negotiations. The new approach introduced the possibility of applying corrective measures during the negotiation process, in order to ensure balance in all chapters. This approach provided greater transparency and inclusiveness in the negotiations and the reform process, while encouraging stakeholder consultation to ensure support in their implementation. The new approach emphasizes that strengthening the rule of law and public administration are the basis for approaching the EU and eventual full membership. The Commission is of the opinion that strengthening the rule of law and democratic administration are crucial for the enlargement process, and that the fulfilment of conditions in the area of justice, freedoms and security of the rule of law, including the fight against organized crime and corruption, will be assessed at an early stage. Negotiation process on Chapters 23 and 24 should be closed only at the end of the process to enable the countries aspiring to EU membership to adopt adequate regulations and improve the work of institutions at the national level within a reasonable period of time with dialogue and financial support provided by the EU from IPA funds.

The Communication from the Commission to the European Parliament, the Council, the European Economic and Social Committee and the Committee of the Regions, Enhancing the Accession Process - A Credible EU Perspective for the Western Balkans from 5 February 2020 proposed revised enlargement methodology. The new methodology should make the process of accession to the European Union more credible, predictable, dynamic, and politically driven as opposed to what was previously considered a "technocratic" process of meeting certain EU technical requirements and standards. Candidates are now required to be credible in terms of their sincere commitment to the fight against corruption, respect for rule of law, ensuring the proper functioning of democratic institutions and public administration, harmonisation with EU common foreign policy instruments, and strengthening regional cooperation and good neighbourly relations. The new methodology also mentions the possibilities of suspending negotiations, rewarding successful candidates, and sanctioning those who do not progress at the expected pace. The largest change introduced by the new methodology is grouping negotiating chapters into six clusters. The essence of this new approach is that key sectors to address the EU accession process should be more strongly emphasised instead of individual chapters, thus establishing a framework for political dialogue and the engagement of political leaders. The first cluster is the most important and deals with the "Fundamentals", which include criteria regarding rule of law, public administration reform, and the economic criteria. This cluster will have a special 
role in the further course of accession negotiations because the overall course of negotiations will depend on the fulfilment of the obligations undertaken in this cluster (Ćemalović, 2020, pp. 281-298).

New methodology was open for Serbia and Montenegro to accept it, while it is obligatory for Albania and North Macedonia. After Serbia and Montenegro accepted a new enlargement methodology, the Council agreed on the application of the revised enlargement methodology to the accession negotiations with Montenegro and Serbia (European Council, 2021). The main advantage of the new methodology is a possibility of the European Commission or member states to request suspension of negotiations if candidate country does not fulfil its obligation in time. While the suspension of negotiations was also included as an option in the old methodology, the way of reaching decisions on suspension is now simplified and based on the decision of the so-called "reverse qualified majority". Another change is that the eventual reopening of this cluster will be more complicated and time-consuming as compared to the existing practice. Simplification of suspension of negotiations should become powerful tool in the EU accession process and implementation of difficult reforms such as those in the rule of law area.

\section{CONCLUSION}

Given the experience of the European Union in the accession process of Romania and Bulgaria, it can be concluded that a new approach for the countries of the Western Balkans was expected. Fulfilment of the rule of law criteria requires, above all, the existence of a satisfactory political dialogue at the national level and an adequate level of engagement of political leaders. The absence of the above was noticed in Romania, where, after many years of efforts, the results achieved in the area of the rule of law the backsliding have been noticed. When it comes to Serbia and Montenegro, it can be concluded that insufficient progress has been made in the area of judicial reform and anti-corruption. Therefore, additional efforts are needed in these areas. A special problem in the Republic of Serbia is the difference in the data presented in the national reports on implementation of the Action plan for Chapter 23 which are activity based compared to the impact assessments in the European Commission reports. Until the adoption of the new methodology of the European Union, such a practice was possible because the previous tools for measuring the level of reforms in the field of justice were inadequate. Research shows that there is a high degree of citizens' distrust in the work of judicial institutions both in Serbia and Montenegro. Therefore, it seems that the introduction of new tools for measuring the fulfilment of criteria in the field of rule of law is of great importance.

An adequate assessment of progress should be contributed by a regional survey based on an analysis of the perceptions and experiences of citizens, businesses, lawyers, service providers and judges, prosecutors and judicial staff. Only in this way is it possible to measure the impact of judicial reforms on efficiency, independence and integrity. In addition to the above, the use of a judicial dashboard is envisaged, which should complement the mentioned surveys by providing reliable statistics and analysis of judicial data.

If we look at the experiences of Romania and Bulgaria, it can be concluded that the process of meeting the criteria and standards of the European Union in the field of rule of law is a long process. Therefore, the approach contained in the new methodology seems justified. The opening of chapters on justice, fundamental rights, rule of law, freedom and security at an early stage should enable not only the harmonization of 
legislation, but also the work and coordination of institutions and proving the fulfilment of criteria. The adoption of a new methodology for grouping negotiation chapters into six areas (clusters) enables the establishment of a framework for political dialogue and a way of engaging political leaders. However, the new approach contains stricter measures. They are reflected in the simplification of the decision to suspend negotiations, while the reopening process is more complex and time-consuming. It should therefore be borne in mind that this is a great responsibility of the countries in the process of negotiating for EU accession, especially having in mind that the negotiation processes started according to a different methodology. Despite the challenges, it should be stressed that EU accession is not only a territorial enlargement, but also implies acceptance of its acquis at the level of candidate countries.

It can be concluded that based on the research applied in this paper, we confirmed the initial assumptions. The new methodology will certainly improve the measurability of the results achieved in the area of rule of law. Although, the new stricter approach might slow down the accession process, Serbia and Montenegro should make the necessary efforts in a timely manner so that new activities do not undermine the previously achieved progress in the rule of law.

\section{BIBLIOGRAPHY:}

Action plan for Chapter 23. Retrieved from:

https://www.mpravde.gov.rs/tekst/9849/finalna-verzija-akcionog-plana-zapregovaranje-poglavlja-23-koja-je-usaglasena-sa-poslednjim-preporukama-ipotvrdjena-od-strane-evropske-komisije-u-briselu-.php (date of access:

23.11.2021).

Albers, P. (2008). Judicial Systems in Europe Compared. In: Van Rhee, C.H. and Uzelac, A. (eds.) Civil Justice between Efficiency and Quality: From Ius Commune to the CEPEJ. Antwerp, Oxford, Portland: Intersetia, pp. 9-25.

Anderson, J., Bernstein, D. S. and Gray, C. W. (2005). Judicial Systems in Transition Economies: Assessing the Past, Looking to the Future. Washington: World Bank.

Annual report of the Judicial Council on overall situation in judiciary for 2020, Montenegro Judicial Council, 2021.

BTI: Transformation Index. Methodology. Available at: https://www.btiproject.org/en/methodology.html\#country-selection (date of access: 23.11.2021).

Butković, H. and Samardžija, V. (2014). Challanges of continued EU enlargement to the Western Balkans - Croatia's experience. Poznan University of Economics Review, 14(4), pp. 91-108.

Council of the EU (2021). Joint press statement EU - Western Balkans: Ministerial Forum on Justice and Home Affairs. Press release 3 December 2021. Retrieved from: https://www.consilium.europa.eu/en/press/press-releases/2021/12/03/jointpress-statement-eu-western-balkans-ministerial-forum-on-justice-and-homeaffairs/ (date of access: 23.11.2021).

Ćemalović, U. (2020). Towards a New Strategy for EU Enlargement - Between the Wish for an Encouragement, the Reality of the Fatigue and the Treat of a Dead End. EU and Comparative Law Issues and Challenges Series (ECLIC), Vol. 4, pp. 281-298. DOI: https://doi.org/10.25234/eclic/11905.

European Council (2021). Application of the revised enlargement methodology to the accession negotiations with Montenegro and Serbia, 06.05.2021, Brussels: 
European Council. Retrieved from:

https://data.consilium.europa.eu/doc/document/ST-8536-2021-INIT/en/pdf (date of access: 23.11.2021).

Gateva, E. (2016). European Union Enlargement Conditionality. London, New York: Palgrave MacMillan.

GRECO (2019). Second compliance report - Montenegro, The fourth evaluation round Corruption prevention in respect of members of parliament, judges and prosecutors. Retrieved from: https://rm.coe.int/cetvrta-runda-evaluacijesprecavanje-korupcije-u-odnosu-na-poslanike-s/16809a5bf3 (date of access: 23.11.2021).

Group of States against corruption (2020). GRECO's Fourth Evaluation Round, "Corruption prevention in respect of members of parliament, judges and prosecutors" Second Compliance Report. Strasbourg: Group of States against corruption and Council of Europe. Retrieved from: https://rm.coe.int/fourthevaluation-round-corruption-prevention-in-respect-of-members-of/1680a07e4d (date of access: 23.11.2021).

Human Rights Action and Monitoring and Research Center (2017). Report on implementation of Judicial Reform Strategy 2014-2016, HRA Montenegro, Podgorica: CEMI, April 2017. Retrieved from: https://cemi.org.me/wpcontent/uploads/2017/04/IZVJE\%C5\%A0TAJ-O-REALIZACIJI-STRATEGIJEREFORME-PRAVOSU\%C4\%90A-2014-2016.pdf (date of access: 23.11.2021).

International Commission of Jurists (2016). Serbia's Judges and Prosecutors: The Long Road to Independent Self-Governance. A Mission Report. Retrieved from: https://www.icj.org/wp-content/uploads/2016/02/Serbia-Long-Road-to-IndepSelf-Gov-Publications-Reports-Fact-Finding-Mission-Report-2016-ENG-1.pdf (date of access: 23.11.2021.).

Kusek, J. Z. and Rist, R. (2004). Ten steps to results-based monitoring and evaluation system: a handbook for development practitioners. Washington: World Bank.

Marić, S. and Bajić, D. (2018). EU's Benchmarking within Chapters 23 and 24 in Accession Negotiations with Serbia - Effects and Challenges. Belgrade: European Policy Center.

Matić Bošković, M. (2017). Management of Court Performance as part of Judicial Accountability. Strani pravni život, 61(2), pp. 77-92.

Pejović, A. A. (2016). Vladavina Prava u politici prijema u Evropsku uniju. Matica Crnogorska, no 66, pp. 7-24.

Rakić Vodinelić, V., Knežević Bojović, A. and Reljanović, M. (2012). Judicial Reform in Serbia 2008-2012. Belgrade: Center for Advanced Legal Studies.

Statistical report on implementation of the Action plan for Chapter 23, July 2018. Retrieved from:

https://www.mpravde.gov.rs/files/Statistical\%20report\%20on\%20implem\%20ent ation\%20of\%20AP\%20for\%20CH\%2023.pdf (date of access: 23.11.2021).

Strategy for the Reform of the Judiciary 2019-2022, Montenegro, Podgorica: Ministry of Justice. Retrieved from: https://www.gov.me/dokumenta/deb3e3ae-7b6a-49639b3e-b5892118c8c8 (date of access: 23.11.2021).

The Charter of the EU Fundamental Rights 2007/C 303/01.

The Global Competitiveness Report, Retrieved from: http://www3.weforum.org/docs/WEF_TheGlobalCompetitivenessReport2019.pd $f$ (date of access: 23.11.2021).

The Treaty establishing the European Economic Community (EEC). Retrieved from: Text is available at: https://eur-lex.europa.eu/legal- 
content/EN/TXT/HTML/?uri=LEGISSUM:xy0023\&from=EN (date of access: 23.11.2021).

The Treaty of Lisbon amending the Treaty on European Union and the Treaty establishing the European Community, 2007/C 306/1. Official Journal of the European Union, C 306/1.

Tomović, P. (2021). 'Koverta' bivšeg gradonačelnika Podgorice neće biti otvorena na Sudu. In: Radio Slobodna Evropa, March 3, 2021. Retrieved from: https://www.slobodnaevropa.org/a/koverta-biv\%C5\%A1eggradona\%C4\%8Delnika-podgorice-ne\%C4\%87e-biti-otvorena-nasudu/31131576.html (date of access: 23.11.2021).

Transparency International (2020). Corruption perception Index 2020. Retrieved from: https://www.transparency.org/en/cpi/2020/index/nzl (date of access: 23.11.2021).

USAID (2018). Rule of Law Project. Assessment of the Implementation of the National Judicial Reform Strategy 2013-2018, 1 November 2018. Retrieved from: https://en.rolps.org/public/documents/upload/Assessment\%20of\%20the\%20NJ RS\%20Implementation,\%20short\%20version,\%20ENG,\%20final,\%2001112018.pd $f$ (date of access: 23.11.2021).

USAID (2020). Opinion Poll Report: Citizen's Perceptions of Anti-Corruption Efforts in Serbia 2020 (III Cycle), November 2020. Retrieved from: https://www.odgovornavlast.rs/wp-content/uploads/2020/12/USAID-GAICitizens'-Perceptions-of-Anticorruption-Efforts-in-Serbia-2020-1.pdf (date of access: 23.11.2021).

Vebsajt RTCG (2019). ZAKON O ZAŠTITI PRAVA NA SUĐENjE U RAZUMNOM ROKU: Neophodno unapređenje Zakona jer ne daje potrebne rezultate. In: Paragraf Lex MNE. Retrieved from: https://www.paragraf.me/dnevnevijesti/20112019/20112019-vijest2.html (date of access: 23.11.2021).

Council of Europe documents:

Venice Commission, Comments on the Provisions on the Judiciary in the Draft Constitution of the Republic of Serbia, CDL (2005) 072, Opinion No. 349/2005, 4 October 2005. Retrieved from:

https://www.venice.coe.int/webforms/documents/?pdf=CDL(2005)072-e (date of access: 23.11.2021).

Venice Commission, Opinion No. 405/2006, Opinion on the Constitution of Serbia, 19 March 2007, para. 60. Retrieved from: https://www.venice.coe.int/webforms/documents/default.aspx?pdffile=CDLAD(2007)004-e (date of access: 23.11.2021).

Venice Commission, Opinion No. 921/2018, Opinion on the draft amendments to the constitutional provisions on the judiciary, 25 June 2018. Retrieved from: https://www.venice.coe.int/webforms/documents/default.aspx?pdffile=CDLAD(2018)011-e (date of access: 23.11.2021).

European Commission documents:

Commission Decision 2006/928/EC of 13 December 2006 establishing a mechanism for cooperation and verification of progress in Romania to address specific benchmarks in the areas of judicial reform and the fight against corruption, Official Journal of the European Union, L 354/56.

Commission Decision 2006/929/EC of 13 December 2006 establishing a mechanism for cooperation and verification of progress in Bulgaria to address specific 
benchmarks in the areas of judicial reform and the fight against corruption and organised crime, Official Journal of the European Union, L 354/58.

Communication from the Commission to the European Parliament and the Council, "Enlargement Strategy and Main Challenges 2012-2013", COM(2012) 600 final. Retrieved from: https://ec.europa.eu/neighbourhoodenlargement/sites/near/files/pdf/key_docu ments/2012/package/strategy_paper_2012_en.pdf (date of access: 23.11.2021).

Communication from the Commission to the European Parliament, the Council, the European Economic and Social Committee and the Committee of the Regions, EU Enlargement Strategy, COM (2015) 611 final. Retrieved from: https://eurlex.europa.eu/legalcontent/HR/TXT/PDF/?uri=CELEX:52015DC0611(01)\&from=EN (date of access: 23.11.2021).

Communication from the Commission to the European Parliament the Council, the European Economic and Social Committee and the Committee of the regions, 2020 Communication on EU enlargement policy. Retrieved from: https://eurlex.europa.eu/legal-content/GA/TXT/?uri=CELEX:52020DC0660 (date of access: 23.11.2021)

Communication from the Commission to the European Parliament, the Council, the European Economic and Social Committee and the Committee of the Regions, A Credible Enlargement Perspective for Enhanced EU Engagement with the Western Balkans, COM (2018) 65 final. Retrieved from: https://eurlex.europa.eu/legal-content/EN/TXT/?uri=CELEX\%3A52018DC0065 (date of access: 23.11.2021).

Communication from the Commission to the European Parliament, the Council, the European Economic and Social Committee and the Committee of the Regions, Enhancing the Accession Process - A Credible EU Perspective for the Western Balkans, COM (2020) 57 final. Retrieved from: https://eur-lex.europa.eu/legalcontent/EN/TXT/PDF/?uri=CELEX:52020DC0057\&from=EN (date of access: 23.11.2021).

Cooperation and Verification Mechanism, $\operatorname{COM(2019)} 499$ final. Retrieved from: https://ec.europa.eu/info/sites/default/files/progress-report-romania-2019-com2019-499_en.pdf (date of access: 23.11.2021).

European Commission (2018a). Report from the Commission to the European Parliament and the Council on Progress in Romania under the Cooperation and Verification Mechanism, $\operatorname{COM(2018)~} 851$ final. Retrieved from: https://eurlex.europa.eu/legal-content/EN/TXT/PDF/?uri=CELEX:52018DC0851\&from=EN (date of access: 23.11.2021).

European Commission (2018b). Serbia 2018 Report, Accompanying the document Communication from the Commission to the European Parliament, the Council, the European Economic and Social Committee and the Committee of the Regions. Retrieved from: https://ec.europa.eu/neighbourhoodenlargement/system/files/2019-05/20180417-serbia-report.pdf (date of access: 23.11.2021).

European Commission (2020). Serbia 2020 Report Accompanying the Communication from the Commission to the European Parliament, the Council, the European Economic and Social Committee and the Committee of the Regions, Communication on EU Enlargement Policy, Brussels: European Commission. Retrieved from: https://ec.europa.eu/neighbourhood- 
enlargement/system/files/2020-10/serbia_report_2020.pdf (date of access: 23.11.2021).

European Commission for the Efficiency of Justice (2020). European judicial systems CEPEJ Evaluation Report, Evaluation cycle (2018 data) Retrieved from: https://www.coe.int/en/web/cepej/special-file-publication-of-the-reporteuropean-judicial-systems-cepej-evaluation-report-2020-evaluation-cycle-2018data- (data access: 23.11.2021).

Report from the Commission to the European Parliament and the Council on Bulgaria's progress on accompanying measures following accession, COM((2007) 377 final. Retrieved from: https://eur-lex.europa.eu/legalcontent/EN/TXT/?uri=CELEX\%3A52018DC0851 (date of access: 23.11.2021).

Report from the Commission to the European Parliament and the Council on Progress Romania's Progress on accompanying measures following accession, $\operatorname{COM}(2007) 387$ final. Retrieved from: https://eur-lex.europa.eu/legalcontent/EN/ALL/?uri=CELEX\%3A52007DC0378 (date of access: 23.11.2021).

Report from the Commission to the European Parliament and the Council on Progress and Verification Mechanism, $\operatorname{COM(2018)~} 851$ final. Retrieved from: https://ec.europa.eu/info/policies/justice-and-fundamental-rights/upholdingrule-law/rule-law/assistance-bulgaria-and-romania-under-cvm/reports-progressbulgaria-and-romania_en (date of access: 23.11.2021).

Report from the Commission to the European Parliament and the Council on Progress in Romania under the Cooperation and Verification Mechanism, COM(2019) 499 final. Retrieved from: https://ec.europa.eu/info/policies/justice-and-fundamentalrights/upholding-rule-law/rule-law/assistance-bulgaria-and-romania-undercvm/reports-progress-bulgaria-and-romania_en (date of access: 23.11.2021).

Report from the Commission to the European Parliament and the Council on progress in Bulgaria under the Cooperation and Verification Mechanism, COM(2019) 498 final. Retrieved from: https://ec.europa.eu/info/sites/default/files/progressreport-bulgaria-2019-com-2019-498_en.pdf (date of access: 23.11.2021).

World Bank documents:

Functional Review of the Prosecution System in Serbia (2019). Washington: World Bank. Retrieved from:

https://www.mdtfjss.org.rs/archive/file/SRB\%20Prosecution\%20FR\%20Decemb er\%202018.pdf (date of access: 23.11.2021).

Serbian Judicial Functional Review 2014. Washington: World Bank. Retrieved from: https://www.mdtfjss.org.rs/archive//file/Serbia\%20Judicial\%20Functional\%20R eview-Full\%20Report.pdf (date of access: 23.11.2021).

World Bank Report (2018). Montenegro - Experiences and Perceptions of Judicial Performance. Washington: World Bank. Retrieved from: https://openknowledge.worldbank.org/bitstream/handle/10986/29813/Montene gro-Experiences-and-perceptions-of-judicial-performance-survey-on-perceptionof-general-population-of-citizens-business-sector-lawyers-judges-publicprosecutors-and-court-administrative-staff.pdf?sequence=5\&isAllowed=y (date of access: 23.11.2021). 
